\title{
THE URGENCY OF CITIZENSHIP COURSE IN PREVENTING STUDENT MORAL DECADENCE IN COLLEGE EDUCATIONS
}

\author{
Amanda Putri Setianingrum ${ }^{1}$, Moses Glorino Rumambo Pandin ${ }^{2}$ \\ ${ }^{1}$ English Literature Study Program, Faculty of Humanities, Universitas Airlangga \\ ${ }^{2}$ Department of English Literature, Faculty of Humanities, Universitas Airlangga \\ ${ }^{1}$ amanda.putri.setianingrum-2020@ fib.unair.ac.id \\ ${ }^{2}$ moses.glorino@fib.unair.ac.id
}

\begin{abstract}
Along with the times, there must be positive impacts and negative impacts in every substance of the era, especially on a person's morals. If we accept positive impacts and apply them in our daily lives, these negative impacts can also be prevented. This does not mean that negative impacts cannot involve and damage human morals. Usually, one can tell whether it is good or bad. He has the feeling of being a person with good morals. Humans tend to do something constructive. Humans who are disrespectful or immoral will tend to commit malicious behavior that is destructive and not following the laws or norms that apply in Indonesia. Integrated education is needed in building human morale that follows the national identity. This article will explain how to process the urgency of citizenship courses to prevent decadence or moral decline, especially among students, and How to be a good citizen with good morality and reduce moral decadence according to civic education in college.
\end{abstract}

Keywords: Moral, Immoral, Law, Norms, Citizenship, Education, Decadence, College 


\section{INTRODUCTION}

Moral decadence is now spreading throughout the world, including our nation. Many people, especially the younger generation today, have been negatively impacted by globalization. Today, people who are moral and immoral are sometimes difficult to distinguish. What is moral and immoral is not seen physically. Our greatest hope is to become moral people and get along with morality and the environment too. Education in Indonesia is currently not well implemented. Especially in terms of character. Character is very important in life. It takes proper training and can answer any problems that arise, such as the inevitable moral decline in this era. Citizenship education itself has officially become a compulsory subject in Indonesia since 1968. The Ministry of Education and Culture of the Republic of Indonesia finally changed civic education to Pancasila Moral Education (Pendidikan Moral Pancasila) or PMP. However, due to the changing times during the reform era, Pancasila Moral Education has returned to citizenship education because the name citizenship education can show the purpose of this course, namely, Indonesian citizens, creating the nation's successor (4). The nation will have a high awareness of nationalism and patriotism. Citizenship education itself, apart from having a general goal of improving the morale of the nation and shaping good character for the younger generation, has several objectives Pancasila Moral Education Returns to citizenship education because citizenship education can show the purpose of this course, namely, Indonesian citizens, to create the nation's successor. This paper aims to emphasize the importance of civic education to prevent moral decadence, especially for today's young generation. The author emphasizes that civic education must be implemented well not only in the compulsory subjects of elementary school, high school, or college, but what is important is how civic education can build a theoretical perspective on how we face globalization, how we apply the positive values of globalization, and how we should prevent and eliminate the negative effects of globalization. Citizenship education will not be carried out well if we are not aware of its negative effects, which will damage our morals gradually. Awareness to realize these negative impacts is something we need to build. Some people allow these negative effects to self-destruct because they do not have a sense of being a good human being. Instead of letting these negative impacts destroy us morally, civic education has an important role in preventing and reducing the negative effects of globalization and westernization that are incompatible with our cultural bases.

1. What is the definition of moral decadence?

2. Why can globalization harm morality? 
3. How important is citizenship education to prevent moral decadence?

4. Who will implement civic education besides students?

\section{WRITING METHOD}

In this journal, the author uses the literature study method. The literature review method itself is defined as a review, reference, study, and personalization of books, scientific literature, journal articles, essays, scientific journals, magazines, and so on that have been previously researched or published. The author chose the literature review method because this method is widely used in scientific paper assignments. This method is appropriate considering that we strongly recommend doing our assignments at home in this pandemic era. In addition, the literature review method is effective. Authors can compare papers one by one and digest the important parts of what the authors have input to this paper. The authors also collected data from open questionnaires to help the authors organize a vote on the urgency of civic education to prevent moral decadence.

\section{RESULTS}

Referring to the questionnaire that the author made from the google form. The results showed that 21 respondents were ranging in age from 21 years to 16 years. The status of respondents is mostly college students and high school students. All 21 respondents agreed that civic education is important to prevent moral decadence. They stated that if citizenship education is not carried out seriously, then a serious moral crisis will occur in the future.

\section{According to you, what is the biggest factors that encouraging moral decadence?} 21 responses

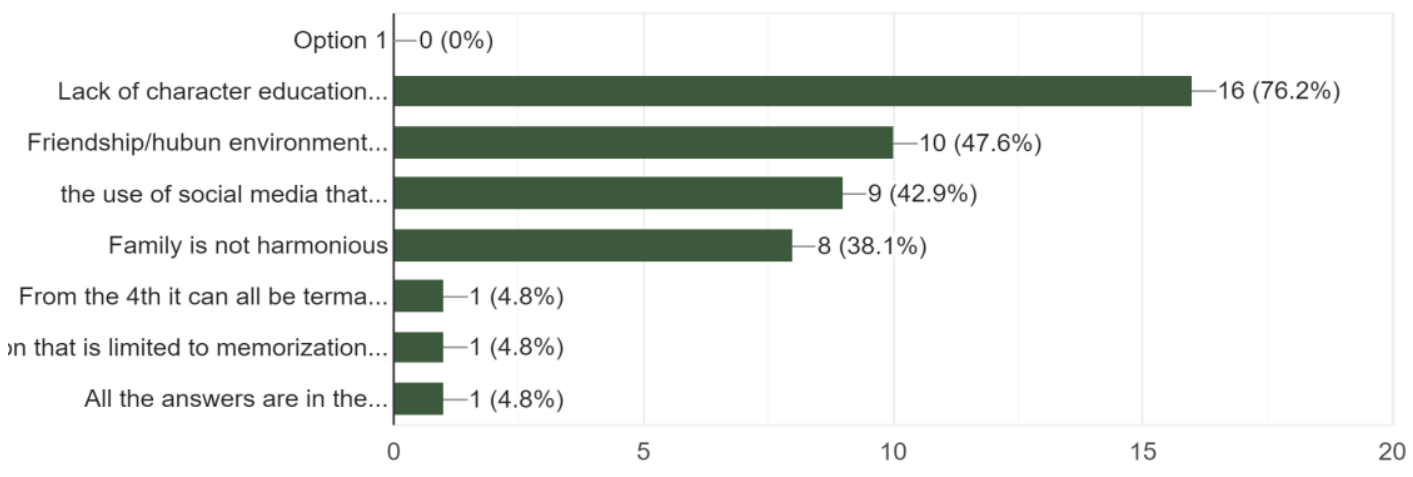


The table is representing respondents' answers about the biggest factors that encourage moral decadence. 16 respondents answer lack character education, religious education, and national education. 10 respondents answer toxicity in relationships. 9 respondents answer unwise usage of social media. 8 respondents answer are not harmonious in family relationships. 3 others are answering for other reasons.

Furthermore, some say that when citizenship education is no longer a compulsory curriculum in tertiary institutions, then the nationalism of students must be questioned. They may lose their real identity, or it can be called an identity crisis. Some say it is important to study and implement civic education, especially for students, to have common sense that controls our behavior towards other people and obeys the rules, norms, and customs.

Most of the respondents stated that if there is no civic education in tertiary institutions, then student morale will gradually deteriorate and eventually disappear (3). They cited the worst possible impact that could happen in the future without civic education, such as a morality crisis, an identity crisis, the exposure of ideologies contrary to Pancasila as the principle of our official ideology (communism, liberalism, socialism, anarchism, etc.), and moral deviations that increase the rate of criminal behavior against the law. This lawless behavior is considered to be the worst result of moral decadence.

\section{DISCUSSION}

The definition of moral decadence itself is general. The diversity of people's viewpoints can affect the original meaning of moral decadence itself. Moral decadence is a condition of a person or group that releases or does not obey the standards of moral values applied in society which destroys people's consciousness to distinguish whether it is good or bad, right or wrong (10). Moral decadence does not directly destroy our morals, but rather gradually and significantly. It may not seem dangerous from the outside. Sometimes, people who have moral consciousness lack decadence, and some of them are in denial of the truth.

Globalization refers to the word "globe," which means the world. According to Selo Soemardjan, the father of Indonesian sociology, globalization is a form of organization and communication between people worldwide by adhering to the same systems and principles. An example is the United Nations (UN), or in English, it is called the United Nations (UN) (11). Many factors influence moral decadence. Most globalization is influenced in every aspect of life. Globalization has indeed changed the order of our lives one by one. Today we have things that make our lives easier, such as gadgets, smartphones, how to dress, slang, fast food, 
multinational companies, economic cooperation, and so on. All the things that make our lives easier are manifestations of globalization. Globalization is marked by progress or improvisation in various aspects, especially aspects of education and communication. Overall, globalization can bring positive values to overcome our limitations. However, something we do not realize about the amount of negativity of globalization is increasing significantly. Globalization creates a higher level of dependence between nations and other wards. It should be noted that the dependence tends to be asymmetric (8). What is meant by asymmetry here? The effect will vary from country to country. Developing countries may be particularly affected. Why is it like that? This is because developed countries or superpowers such as the United States and China have greater power and dominate other countries in the political and economic fields. Furthermore, developing countries must be followed by the greatest influence of the two countries to be equated with superpowers. Globalization changes the way people think, the way people act, and the way people behave. People affected by globalization tend to behave like western cultures rather than eastern cultures. Worse, when residents continue to follow western trends and do not maintain our local pride and cultural base, it can trigger other problems starting from globalization such as hedonism, consumerism, individualism, pragmatics, materialism, and secularism. These six things are examples of lifestyle changes that have greater power to destroy the cultural basis, morality, and identity of the world's nations. Globalization greatly affects young people, referring to the Millennial generation, Generation Z, and the Alpha generation. Just look at today's teenagers. They tend to follow their idol appearance. The young generations nowadays are more advanced in technology compared to their parents. They talk a lot in slang, even curse not only to their friends but also to their parents. Ironically, nowadays, people, especially the millennial generation, generation $\mathrm{Z}$, and alpha generation, cannot sing the national anthem. They cannot memorize the names of national heroes, do not even know the five points of Pancasila. However, they can name celebrities, football players, YouTube video makers, and so on. In Indonesia, norms are upheld. Norms are respected and applied in social life. Each region applies different norms, but the intentions are the same. To maintain good behavior in society and differentiate what we should do and what we should not do to maintain peace in life. Globalization can change the norms that are applied in Indonesia. People today cannot maintain good manners due to cultural shocks, and cultural inertia is the common reason why people cannot withstand the negative effects of globalization. Globalization can also damage the ecology and environment around us. Due to technological developments, many natural resources have been damaged because they are exploited on a large scale by parties who are not responsible for environmental 
sustainability and are only concerned with personal or group gain. If allowed to continue, then the surrounding environment can be damaged, and natural disasters caused by human activity can arise. Some people do not understand the urgency of the norms and rules of life. In addition, they also lose their self-respect and forget their national identity. Two factors primarily influence moral decadence. The first is internal factors. Internal factors resulting from personality and personal habits are also a stage of growth over the years. Second, external factors are influenced by external parties or the surrounding environment. It can be influenced by the lifestyle of their family, relatives, or friends. (5) Dignity is the most important thing that we should hold firmly wherever we are. When we lose our dignity and self-respect, there is nothing left to prevent the negative effects of globalization. The worst thing that may happen in the future is that something we cannot predict is to lose who we are and continue to be swayed by the negative effects of globalization. Building good behavior, developing good character, and filtering new things wiser are the basic keys to preventing globalization. Globalization cannot be stopped. Nevertheless, we have to remember that there are positives and negatives to everything in this world. Apply the positives and get rid of the negatives. We do not need to block globalization. All we need is to filter the waves of globalization. Furthermore, filtering new things wisely is the basic key to preventing the impact of globalization.

According to Zamroni, civic education aims to build democratic thinking and build awareness to develop good character as a local community. (7) There are at least five reasons why civic education is needed to be included in our education system. First, building local nationalism. Second, build awareness about patriotism. Third, Indonesians must believe that our ideology is the only Pancasila and cannot be changed by anything else. Fourth, emphasizing that human rights are the most important thing in life that we must protect at all costs. Moreover, the fifth sincerely participate in defending the country to prevent military and nonmilitary threats. (6) The vision of citizenship education is to build community participation to develop and manifest their character to become a human being. In addition, civic education has the vision to develop intellectual, religious, dignified, humanist, nationalist, and patriotic behavior. The six components mentioned are the basic criteria of the civic education vision. The mission of civic education can enlarge this. (9) The mission of citizenship education here is to encourage students to build their character, consistently apply the principles of Pancasila in their lives. Building a sense of nationalism and patriotism, expanding knowledge to save civilization. (1) Citizenship education is very important to prevent moral decadence. 
Citizenship education requires people to maintain their good deeds. Sometimes, the desire to be superior, selfish, individualistic, and apathetic is due to our personality environment. It can lead us to moral decadence when we are still doing bad deeds to ourselves and others.

Students should know that civics education is important, and we should not miss the civic education curriculum. It is not surprising that citizenship education has been implemented since elementary school, high school, and college. The substance of civic education is not limited to the subjects we usually learn during Civics classes, and after the class ends, everything disappears like nothing is left. Citizenship education must be applied in our lives, Not only students who have to implement civic education in life. All Indonesian citizens must implement the vision and mission of citizenship education. Remember that civic education does build character as a human being and engenders humanist behavior. Whether it is young and old, we must have good manners to build a good life for each other. Respecting others is the best way to get a sense of peace in life. Mutual respect, tolerance, tolerance, and empathy with fellow human beings are also very helpful to prevent moral decadence (2)

Globalization cannot be stopped; we cannot block or isolate access to globalization. However, we can prevent it by maintaining good character, obeying the rules, building selfdefense, developing self-esteem, studying the substance of civic education, being humanist, nationalist, respecting others, always being positive, and using common sense is the key to preventing moral decadence is increasing today. We may have been involved in the negative effects of globalization which lost our moral values. Isn't it too late to be a better person in the future? As students, we must become agents of change who can go beyond the positive side of life. Awareness to become a better person starts with ourselves. Globalization cannot be changed, but we can change the negative way to the positive way. Kindness starts with ourselves, and the most valuable thing is that we give our best to remove the negativity and change it to a better way.

\section{REFERENCES}

1. Lestari L. Youth Moral Decadence (Efforts to Build Morals by Families and Schools). J Social Educator and Hum. 2021; 12 (1): 7.

2. Erviana VY. Handling Moral Decadence through the Application of Characters of Love for Peace and Nationalism. J Researcher Science Educator. 2021; 14 (1): 19. 
3. Ulfah N, Suyitno. Analysis of Learning Approaches for General Compulsory Subjects in Pancasila and Citizenship Education in Higher Education. J Pancasila and Citizenship. 2019; 4 (1): 22-33.

4. Darma IDGD. DEALING WITH ETHICS AND MORAL DEGRADATION AS. Journal of Religious Educators. 2021; 8 (1): 46-64.

5. Nurhakim YF, Dewi DA. The Role of Citizenship Education in Building Character in Millennial Generation Children. J WEEK J Citizenship Educator. 2021; 6 (1): $116-25$.

6. Elza A, Dewi DA. THE IMPORTANCE OF CITIZENSHIP EDUCATION ALSO THE APPLICATION AND RELEVANCE IN LIFE IN THE ERA OF MILLENNIAL GENERATION TECHNOLOGY. J The Citizenship Educator. 2021; 3 (4): 6 .

7. Regi P, Anggraeni D. Social Construction: Journal of Social Science Research on Citizenship Education concerning Character Education in Indonesia. Journal of Social Science Research. 2021; 1 (2): 33-40.

8. Nurul I, Dewi DA. Pancasila Cries for the Moral Deterioration of the Nation's Young Generation. J Assess Educators. 2021; 3 (1): 185-97.

9. Joko W, Intan K, Ahmad NAB. A Comprehensive Approach to Learning Pancasila and Citizenship Education. Acad Educ J. 2021; 12 (2): 179-89.

10. Fitri SFN, Dewi DA. THE IMPORTANCE OF CITIZENSHIP EDUCATION IN THE ERA OF GLOBALIZATION IN PREVENTING MORAL DEGRADATION. J Chem Inf Model. 2021; 53 (9): 1689-99.

11. Ahmad. Understanding Globalization [internet]. 2021. Retrieved 27 May 2021 from $\underline{\sqrt{ } 10+\text { Understanding Globalization in General and According to Experts }}$ (yuksinau. id) 
